\title{
Effects on Rat Fetuses of Intrauterine Injections of Insulin
}

\author{
L. Angervall, K. Karlsson, and A. Martinsson \\ Department of Pathology II, University of Göteborg, Göteborg and Department of Clinical Chemistry, \\ Mölndal County Hospital, Mölndal, Sweden
}

Summary. The effects on rat fetuses of a single intrauterine injection of long-acting insulin with respect to length, body and organ weights, total lipids, phospholipids, cholesterol, neutral fat, total nitrogen and water content were investigated. At the age of 498 hours the fetuses were injected in utero with $2 \mathrm{IU}$ of long-acting insulin or a control solution. Twenty-four hours after the injections the insulintreated fetuses weighed about 10 per cent more than the control fetuses, $5.32 \pm 0.05 \mathrm{~g}$ (75 fetuses) and $4.85 \pm 0.05$ (73 fetuses) respectively $(\mathrm{p}<0.001)$. The body lengths were $54.1 \pm 0.2 \mathrm{~mm}$ and $52.9 \pm$ $0.2 \mathrm{~mm}$ respectively $(\mathrm{p}<0.001)$. The insulin-treated fetuses had higher organ weights and higher content of total lipids, phospholipids and neutral fat. The amount of total lipids was higher in insulin-treated fetuses even after taking into account differences in body weight, suggesting that the insulin-treated fetuses were obese. The finding of significantly lower water content in insulin-treated fetuses at equal body weight is consistent with the higher fat content. There was no increase in total nitrogen or length in the fetuses in the insulin-treated group compared to control fetuses at equal body weight indicating that the administered insulin mobilized maternal proteins and that protein, as well as length, increased proportionately to overweight. For quantitative analysis of morphological and biochemical variables dependent upon body weight, as in this investigation, multivariate analysis is indispensable.

Key words: Pregnant rat, insulin in utero, fetal body weight and length, biochemical composition, multivariate analysis.

The excess weight of infants of diabetic mothers is commonly attributed to increased production of insulin by the fetal pancreas in response to maternal hyperglycaemia. The observation of an increased neutral fat content without increase of other lipids in newborn offspring of alloxan-diabetic rats suggests an increase of depot fat in these newborn rats compared to newborn control rats of equal body weight [2]. From these experiments, and a previous study [1], it may be concluded that overweight newborn offspring of alloxan-diabetic rats are abnormally long as well as abnormally obese.

Table 1. Conception weights, parturition weights, total amounts of insulin injected in utero into the fetuses, and glucose levels in the mother rats before parturition (mean $\pm S E M$ )

\begin{tabular}{|c|c|c|c|c|c|c|c|}
\hline \multirow[b]{2}{*}{ Experiment } & \multirow[b]{2}{*}{ No. of rats } & \multirow[b]{2}{*}{$\begin{array}{l}\text { Body weight at } \\
\text { conception } \\
\text { (g) }\end{array}$} & \multirow[b]{2}{*}{$\begin{array}{l}\text { Body weight at } \\
\text { parturition } \\
\text { (g) }\end{array}$} & \multirow[b]{2}{*}{$\begin{array}{l}\text { Mean dose of } \\
\text { insulin per } \\
\text { mother rat } \\
\text { (IU) }\end{array}$} & \multicolumn{3}{|c|}{ Blood glucose $(\mathrm{mg} / \mathrm{dl})$} \\
\hline & & & & & $\begin{array}{l}498 \mathrm{~h} \text { after } \\
\text { conception } \\
\text { (day } 21 \text { ) } \\
\text { in the tail vein }\end{array}$ & $\begin{array}{l}522 \mathrm{~h} \text { after } \\
\text { conception } \\
\text { (day 22) } \\
\text { in the tail vein }\end{array}$ & $\begin{array}{l}522 \mathrm{~h} \text { after } \\
\text { conception } \\
\text { (day } 22 \text { ) } \\
\text { in the jugular } \\
\text { vein }\end{array}$ \\
\hline A & 12 & $247 \pm 8$ & $274 \pm 6$ & $12.5 \pm 0.9$ & $68 \pm 4$ & $91 \pm 3$ & $104 \pm 3$ \\
\hline $\mathrm{B}$ & 15 & $233 \pm 7$ & $268 \pm 7$ & $12.4 \pm 0.8$ & $69 \pm 1$ & $92 \pm 3$ & $104 \pm 3$ \\
\hline
\end{tabular}


Table 2. Birth weights and lengths of insulin-treated and control fetuses (mean \pm SEM). P-values for the difference between means tested by Student's t-test are given

\begin{tabular}{|c|c|c|c|c|c|c|}
\hline \multirow[b]{2}{*}{ Groups } & \multirow[b]{2}{*}{$\begin{array}{l}\text { No. of } \\
\text { young }\end{array}$} & \multirow[b]{2}{*}{ No. of litters } & \multicolumn{2}{|l|}{ Weight (g) } & \multicolumn{2}{|c|}{ Length (mm) } \\
\hline & & & $\begin{array}{l}\text { Mean birth } \\
\text { weight }\end{array}$ & $\begin{array}{l}\text { Mean litter } \\
\text { weight }\end{array}$ & $\begin{array}{l}\text { Mean birth } \\
\text { length }\end{array}$ & $\begin{array}{l}\text { Mean litter } \\
\text { length }\end{array}$ \\
\hline $\begin{array}{l}\text { Experiment A } \\
\text { Insulin-treated }\end{array}$ & 71 & 12 & $5.32 \pm 0.05$ & $5.36 \pm 0.06$ & $54.1 \pm 0.2$ & $54.2 \pm 0.2$ \\
\hline $\begin{array}{l}\text { Controls treated } \\
\text { with saline }\end{array}$ & 73 & 12 & $\begin{array}{l}4.85 \pm 0.05 \\
p<0.001\end{array}$ & $\begin{array}{l}4.85 \pm 0.07 \\
p<0.001\end{array}$ & $\begin{array}{l}52.9 \pm 0.2 \\
p<0.001\end{array}$ & $\begin{array}{l}52.9 \pm 0.3 \\
\mathrm{p}<0.001\end{array}$ \\
\hline $\begin{array}{l}\text { Experiment } \mathbf{B} \\
\text { Insulin-treated }\end{array}$ & 89 & 15 & $5.33 \pm 0.05$ & $5.39 \pm 0.08$ & $54.6 \pm 0.1$ & $54.6 \pm 0.2$ \\
\hline $\begin{array}{l}\text { Controls treated } \\
\text { with supernatant }\end{array}$ & 91 & 15 & $\begin{array}{l}4.87 \pm 0.05 \\
p<0.001\end{array}$ & $\begin{array}{l}4.84 \pm 0.09 \\
p<0.001\end{array}$ & $\begin{array}{l}53.5 \pm 0.2 \\
p<0.001\end{array}$ & $\begin{array}{l}53.5 \pm 0.3 \\
p<0.001\end{array}$ \\
\hline
\end{tabular}

In experiments with repeated fetal injections of protamine-zinc insulin for three days at the end of the gestation, Picon [10] found higher "fresh weight", dry weight, total lipids and nitrogen in the insulin-treated offspring than in the controls. In contrast to other experiments [2], the biochemical components were not compared in experimental and control fetuses of equal body weight. Picon [10] concluded that the results of biochemical analyses showed that insulin had promoted "true growth".

The aim of this study was to investigate the effects on rat fetuses of a single intrauterine injection of long-acting insulin with respect to length, body and organ weights, total lipids, phospholipids, cholesterol, neutral fat, total nitrogen and water content. These variables were compared with those of control fetuses. The results of the biochemical analysis and determination of length and organ weights were corrected for differences in body weight between the insulin and control fetuses.

\section{Material and Methods}

\section{Experimental Procedures}

Two experiments, $\mathrm{A}$ and $\mathrm{B}$, were performed, the difference being the control solution used. In experiment $A$ the control fetuses were given $0.05 \mathrm{ml}$ of saline solution, $0.154 \mathrm{~mol} / 1$. In experiment B they were given $0.05 \mathrm{ml}$ of a supernatant obtained after centrifugation of a suspension of Novo Ultralente insulin.

In experiment $\mathrm{A}$ twelve pregnant rats were used. Altogether they had 148 fetuses, which were divided into two groups as follows:

1) Insulin-treated, i. e. fetuses injected with $0.05 \mathrm{ml}$ of insulin suspension containing $2 \mathrm{IU}$ insulin, $\mathrm{n}=75$.

2) Controls, i. e. fetuses injected with $0.05 \mathrm{ml}$ of $0.154 \mathrm{~mol} / 1$ saline solution, $\mathrm{n}=73$.
In experiment B fifteen pregnant rats were used. They had 185 fetuses altogether, which were divided into two groups as follows:

1) Insulin-treated fetuses as in experiment $A, n=93$.

2) Controls: fetuses injected with $0.05 \mathrm{ml}$ of supernatant, $\mathrm{n}=92$.

The experiments were performed on unmated female albino rats of a Sprague-Dawley strain supplied by Anticimex $A B$, Stockholm, Sweden. The rats were mated as described in a previous paper [3].

After 498 hours' gestation the rat was anaesthetized with ether and the abdominal cavity was opened by a medial incision. The fetuses were gently lifted out and placed on a cloth spread over the mother's abdomen. The fetuses were numbered from the ovary down and alternate fetuses randomly injected in a hind leg with insulin or control solution. The fetuses were replaced and the abdomen closed with silk sutures. The abdominal wall was sprayed with an aerosol with a bactericidal and fungicidal action (Nobecu$\tan ^{\circledR}$, Bofors, Nobel-Pharma, Sweden).

In preliminary experiments the fetuses were given 0.5 or $1 \mathrm{IU}$ of Novo Ultralente insulin, which they seemed to tolerate well. The dose was therefore increased to $2 \mathrm{IU}$, which was then used throughout the experiments.

Twenty-four hours after the injections, after a gestation time of 522 hours, the fetuses were removed by Caesarian section with the mother again under ether anaesthesia. The young were immediately weighed and measured for length as described previously [1]. Organs of the fetuses and the mother rats were weighed as described previously [3]. Some of the fetuses - as a rule two from each litter - were decapitated, frozen at $-20^{\circ} \mathrm{C}$ and used for chemical analysis.

\section{Biochemical Methods}

Maternal blood samples for glucose determination were drawn from the tail vein and the jugular vein. Duplicate $0.05 \mathrm{ml}$ blood samples were always drawn from the mother rats. For blood glucose determination in the fetuses, samples were taken following decapitation. Whenever possible, glucose determinations were performed on two specimens. All glucose values were determined by a glucose oxidase method [11].

The frozen carcasses were homogenized in $5 \mathrm{ml}$ of redestilled water for two minutes with an Ultra-Turrax homogenizer operating at $10000 \mathrm{rpm}$. The total homogenate was weighed, immedi- 
Table 3. Absolute organ weights in insulin-treated and control fetuses (mean $\pm S E M$ ). P-values for the difference at equal body weights are given

\begin{tabular}{|c|c|c|c|c|c|c|}
\hline \multirow[b]{2}{*}{ Groups } & \multicolumn{6}{|c|}{ Organ weight (mg) } \\
\hline & Adrenals & Thymus & Spleen & Kidneys & Testes & Liver \\
\hline \multicolumn{7}{|l|}{ Experiment A } \\
\hline Insulin-treated & $\begin{array}{l}2.42 \pm 0.04 \\
(n=49)\end{array}$ & $\begin{array}{l}10.01 \pm 0.21 \\
(n=49)\end{array}$ & $\begin{array}{l}8.14 \pm 0.21 \\
(n=49)\end{array}$ & $\begin{array}{l}41.0 \pm 0.7 \\
(n=49)\end{array}$ & $\begin{array}{l}4.65 \pm 0.12 \\
(n=25)\end{array}$ & \\
\hline $\begin{array}{l}\text { Controls treated } \\
\text { with saline }\end{array}$ & $\begin{array}{l}2.22 \pm 0.04 \\
(\mathrm{n}=51) \\
\mathrm{p}<0.05\end{array}$ & $\begin{array}{l}9.47 \pm 0.16 \\
(\mathrm{n}=51) \\
\text { n.s. }\end{array}$ & $\begin{array}{l}7.14 \pm 0.14 \\
(\mathrm{n}=51) \\
\text { n.s. }\end{array}$ & $\begin{array}{l}36.5 \pm 0.4 \\
(\mathrm{n}=51) \\
\text { n.s. }\end{array}$ & $\begin{array}{l}4.14 \pm 0.08 \\
(n=26) \\
\text { n.s. }\end{array}$ & \\
\hline \multicolumn{7}{|l|}{ Experiment B } \\
\hline Insulin-treated & $\begin{array}{l}2.34 \pm 0.05 \\
(n=60)\end{array}$ & $\begin{array}{l}10.14 \pm 0.19 \\
(n=60)\end{array}$ & $\begin{array}{l}8.84 \pm 0.18 \\
(n=60)\end{array}$ & $\begin{array}{l}39.5 \pm 0.5 \\
(n=60)\end{array}$ & $\begin{array}{l}4.50 \pm 0.09 \\
(n=26)\end{array}$ & $\begin{array}{l}370.3 \pm 5.8 \\
(\mathrm{n}=50)\end{array}$ \\
\hline $\begin{array}{l}\text { Controls treated } \\
\text { with supernatant }\end{array}$ & $\begin{array}{l}2.13 \pm 0.04 \\
(n=62) \\
p<0.05\end{array}$ & $\begin{array}{l}9.39 \pm 0.17 \\
(n=62) \\
p<0.01\end{array}$ & $\begin{array}{l}7.28 \pm 0.16 \\
(n=62) \\
\text { n.s. }\end{array}$ & $\begin{array}{l}34.9 \pm 0.5 \\
(\mathrm{n}=62) \\
\mathrm{p}<0.01\end{array}$ & $\begin{array}{l}3.83 \pm 0.09 \\
(n=27) \\
\text { n.s. }\end{array}$ & $\begin{array}{l}322.1 \pm 5.1 \\
(n=56) \\
p<0.01\end{array}$ \\
\hline
\end{tabular}

ately frozen, transferred to a freeze-drier for $48 \mathrm{~h}$ and further dessicated under vacuum over phosphorous pentoxide to constant weight. The total body content of water was calculated as the difference between the wet weight and the dry weight. The dried tissue was then extracted three times with chloroform-methanol, $2: 1(\mathrm{v} / \mathrm{v}), 50 \mathrm{ml}$ each time, and the extract processed as described by Folch et al. [5]. Aliquots of the washed chloroform infranatant were taken for determination of total lipids and phospholipids after determination of lipid phosphorous [12], using a factor of 25 when lipid phosphorous was converted to phospholipid. Another aliquot of the chloroform infranatant was used for determination of cholesterol as follows: the chloroform was evaporated and the lipids were redissolved in isopropanol and vigorously shaken with sialic acid, and Lloyd reagent, $\mathrm{CuSO}_{4}, 10 \mathrm{H}_{2} \mathrm{O}$ and $\mathrm{Ca}(\mathrm{OH})_{2}$ [6] and assayed according to the method of Levine and Zak [7]. The residual weight after subtraction of the weights of cholesterol and phospholipids was assumed to represent neutral fat. Total nitrogen was determined on the total delipidised tissue using a macro-Kjelldahl procedure.

\section{Statistical Methods}

The following multivariate non-parametric technique was used to eliminate the influence of birth weight on the morphological and biochemical variables studied. The fetuses were divided into small sub-groups according to birth-weight so that the mean birth weights were the same for insulin-treated and control fetuses within each sub-group. For studying possible differences of the variables between insulin-treated and control fetuses, Fisher's non-parametric permutation test-variable was calculated for each sub-group [9]. The results from the different sub-groups were pooled into a summarizing test [8]. For determination of the p-values of the summarizing test, an accurate method using Edgeworth's expansion was used.

For testing other differences, Student's t-test was used.

\section{Results}

Mean conception and parturition weights, mean total dose of insulin per mother rat and mean blood glucose values for the mother rats are given in Table 1 .
There were no statistically significant differences between experiment $\mathrm{A}$ and $\mathrm{B}$ in these variables.

\section{Offspring}

Birth weights and lengths of the offspring are shown in Table 2. In experiment $A$ four of the insulintreated fetuses died before parturition and were excluded from further study. The 71 insulin-treated fetuses had a mean birth weight of $5.32 \pm 0.05 \mathrm{~g}$, compared with $4.85 \pm 0.05 \mathrm{~g}$ in the 73 control fetuses $(p<0.001)$. The mean litter weights also differed significantly. The mean birth length and litter length were higher in the insulin-treated group than in the control group ( $p<0.001$ for both differences).

In experiment $B$ four insulin-treated and one control fetus died before parturition and were excluded. Mean body weights and lengths were similar to experiment $\mathrm{A}$. Comparison at equal body weight showed no significant difference in length between the groups.

Table 3 gives the absolute organ weights of adrenals, thymus, spleen, kidneys, testes and liver. All were significantly heavier in the insulin-treated group. Statistically significant differences were found at equal body weight in experiment $\mathrm{A}$ for adrenals and in experiment $B$ for adrenals, thymus, kidneys and liver.

Table 4 shows the mean value \pm SEM for total lipids, phospholipids, cholesterol, neutral fat, total nitrogen and water content in experiment $B$, as well as the mean birth weights for the fetuses used for chemical analysis. Significantly higher values were found in the insulin group for all lipid fractions and total nitrogen when Student's t-test was used. Mul- 
Table 4. Means and standard errors in the insulin-treated and control groups for total lipids, phospholipids, cholesterol, neutral fat, total nitrogen, water content and birth weight. P-values for the difference at equal body weight are given

\begin{tabular}{llllllll}
\hline Groups & $\begin{array}{l}\text { Total lipids } \\
(\mathrm{mg})\end{array}$ & $\begin{array}{l}\text { Phospholipids } \\
(\mathrm{mg})\end{array}$ & $\begin{array}{l}\text { Cholesterol } \\
(\mathrm{mg})\end{array}$ & $\begin{array}{l}\text { Neutral fat } \\
(\mathrm{mg})\end{array}$ & $\begin{array}{l}\text { Total nitrogen } \\
(\mathrm{mg})\end{array}$ & $\begin{array}{l}\text { Water content } \\
(\%)\end{array}$ & $\begin{array}{l}\text { Birth weight } \\
(\mathrm{g})\end{array}$ \\
\hline $\begin{array}{l}\text { Insulin- } \\
\text { treated }\end{array}$ & $\begin{array}{l}63.17 \pm 1.09 \\
(\mathrm{n}=14)\end{array}$ & $\begin{array}{l}32.31 \pm 0.98 \\
(\mathrm{n}=14)\end{array}$ & $\begin{array}{l}2.11 \pm 0.04 \\
(\mathrm{n}=14)\end{array}$ & $\begin{array}{l}28.74 \pm 0.82 \\
(\mathrm{n}=14)\end{array}$ & $\begin{array}{l}70.98 \pm 0.89 \\
(\mathrm{n}=15)\end{array}$ & $\begin{array}{l}86.57 \pm 0.16 \\
(\mathrm{n}=15)\end{array}$ & $\begin{array}{l}5.32 \pm 0.10 \\
(\mathrm{n}=15)\end{array}$ \\
Controls & $\begin{array}{l}47.72 \pm 1.92 \\
(\mathrm{n}=15)\end{array}$ & $\begin{array}{l}26.94 \pm 0.90 \\
(\mathrm{n}=15)\end{array}$ & $\begin{array}{l}1.87 \pm 0.06 \\
(\mathrm{n}=15)\end{array}$ & $\begin{array}{l}18.91 \pm 1.14 \\
(\mathrm{n}=15)\end{array}$ & $\begin{array}{l}65.73 \pm 1.90 \\
(\mathrm{n}=15)\end{array}$ & $\begin{array}{l}86.71 \pm 0.08 \\
(\mathrm{n}=15)\end{array}$ & $\begin{array}{l}\mathrm{n}=1.81 \pm 0.13 \\
(\mathrm{n}=15)\end{array}$ \\
& $\mathrm{p}<0.01$ & $\mathrm{p}<0.05$ & n.s. & 0.01 & n.s. & $\mathrm{p}<0.05$ & \\
\hline
\end{tabular}

Table 5. Blood glucose levels in insulin-treated and control fetuses (mean $\pm \mathrm{SEM})$

\begin{tabular}{lll}
\hline & \multicolumn{2}{l}{ Blood glucose $(\mathrm{mg} / \mathrm{dl})$} \\
\cline { 2 - 3 } Groups & Mean birth level & Mean litter level \\
\hline $\begin{array}{l}\text { Experiment A } \\
\text { Insulin-treated }\end{array}$ & $\begin{array}{l}143 \pm 8 \\
(\mathrm{n}=31)\end{array}$ & $\begin{array}{l}155 \pm 10 \\
(\mathrm{n}=10)\end{array}$ \\
$\begin{array}{l}\text { Controls treated } \\
\text { with saline }\end{array}$ & $\begin{array}{l}141 \pm 7 \\
(\mathrm{n}=29)\end{array}$ & $\begin{array}{l}140 \pm 8 \\
(\mathrm{n}=10)\end{array}$ \\
$\begin{array}{l}\text { Experiment } \mathrm{B} \\
\text { Insulin-treated }\end{array}$ & $\begin{array}{l}133 \pm 7 \\
(\mathrm{n}=52)\end{array}$ & $\begin{array}{l}132 \pm 6 \\
(\mathrm{n}=13)\end{array}$ \\
$\begin{array}{l}\text { Controls treated } \\
\text { with supranatant }\end{array}$ & $\begin{array}{l}130 \pm 4 \\
(\mathrm{n}=54)\end{array}$ & $\begin{array}{l}128 \pm 4 \\
(\mathrm{n}=13)\end{array}$ \\
\hline
\end{tabular}

tivariate analysis showed that the insulin-treated fetuses contained significantly more total lipids, phospholipids and neutral fat than the controls at equal body weight, but there was no significant difference in cholesterol or total nitrogen. There was no significant difference in water content between the groups when Student's t-test was used. However, comparison at equal body weight showed a significantly lower water content in the insulin-treated fetuses.

There was no statistically significant difference in blood glucose levels between the insulin-treated and control fetuses in either experiment (Table 5).

\section{Discussion}

In this investigation certain morphological and biochemical variables which are dependent upon the body weight (birth weight) were studied. A nonparametric multivariate analysis which makes it possible to compare the variables at equal body weight was used. This is mandatory in investigations of this type and distinguishes this investigation from previous studies, e. g. that of Picon [10].
Two experiments were performed. In experiment A the control fetuses were injected with a saline solution. However, the effect of the insulin solution might be influenced by the vehicle. Therefore, in experiment B the control fetuses were injected with a supernatant in order to detect any influence of the vehicle. The conformity of the results in the two experiments indicates that insulin administration per se was responsible for the increased fetal growth and changes of the biochemical composition.

The investigation has revealed that a single injection of long-acting insulin into fetuses after 498 hours' gestation resulted in significantly increased length and weight 24 hours later in comparison with control fetuses. The insulin-injected fetuses showed significantly higher weights of the studied organs, total lipids, the different lipid fractions and total nitrogen but not of water content. The findings for total lipids and total nitrogen are in principle in agreement with those of Picon [10]. After correction for differences in body weight between the two groups by non-parametric multivariate analysis, there was a variable increase in organ weight but no increase in length. However, there were still significantly greater amounts of total lipids, phospholipids and neutral fat. These observations suggest that the insulin-treated fetuses were obese. Correction for difference in body weight also revealed a significantly lower water content in the insulin-injected fetuses. This is consistent with the higher fat content in the fetuses as fat has a lower water content than "lean body mass" [4]. There was no increase in total nitrogen or length in the fetuses in the insulin-treated group compared to control fetuses at equal body weight, indicating that the administered insulin mobilized maternal proteins and that protein, as well as length, increased proportionately to overweight.

\section{References}

1. Angervall L (1959) Alloxan diabetes and pregnancy in the rat. Effects on offspring. Acta Endocrinol (Kbh) 31 [Suppl 44] 
2. Angervall L, Björntorp P, Martinsson A (1965) Lipids in newborn of alloxan-diabetic rats. Diabetes 14: 724-728

3. Angervall L, Martinsson A (1969) Overweight in offspring of cortisone-treated pregnant rats. Acta Endocrinol (Kbh) 60: 36-46

4. Behnke AP (1953) Relation of lean body weight to metabolism and some consequent systematizations. Ann NY Acad Sci 56: $1095-1142$

5. Folch J, Ascoli I, Lees M, Meath JA, LeBaron FN (1951) Preparation of lipids extract from brain tissue. J Biol Chem 191: 833-841

6. Kessler G, Lederer H (1966) Fluorometric measurements of triglycerides. In: Skeggs Jr LT (ed) Automation in analytical chemistry. Technicon Symposium 1965. Mediad, New York, p 341-344

7. Levine JB, Zak B (1964) Automated determination of serum total cholesterol. Clin Chim Acta 10: 381-384

8. Mantel N (1963) Chi-square tests with one degree of freedom; extensions of the Mantel-Hoenslyel procedure. J Am Statist Ass 58: 690-700
9. Odén A, Wedel H (1975) Arguments for Fisher's permutation test. Ann Statistics 3: 518-520

10. Picon L (1967) Effects of insulin on growth and biochemical composition of the rat fetus. Endocrinology 81: 1419-1421

11. Teller JD (1956) Direct quantitative colorimetric determination of serum or plasma glucose (Abstr). 130th Meeting Am Chem Soc, p 69C

12. Zilversmit DB, Davis AK (1950) Microdetermination of plasma phospholipids by trichloracetic acid and precipitation. $\mathrm{J}$ Lab Clin Med 35: 155-160

Received: February 12, 1980,

and in revised form: November 3, 1980

Lennart Angervall, M. D.

Department of Pathology II

Sahlgren's Hospital

S-41345 Göteborg

Sweden 